\title{
the girl with many heads
}

\author{
Beth Goobie
}

Le grotesque, comme Mary Russo l'a démontré, est souvent associé avec le féminin - et avec la trope féminine privilégiée, le corps. Dans "La fille aux plusieurs têtes," le corps grotesque est conçu comme un corps social carnavalesque, une parade de genres abjects et comme une image d'un sujet sans dessus-dessous, son sujet proliférant présenté sous la forme de multiples appendices - des mains et des têtes. La maison de verre, qui nous rappelle la prolifération d'illusions du baroque est là pour avoir un aperçud'un sujet déjà plein, mobile et hétérogène, et non pour créer une image multiple d'un sujet unifié.

the carnival splays, network of nerves brilliant in its evening skin, gatekeepers raucous about the entry fee. into mouths of cotton candy, through the buttery glow of popcorn machines, strides the girl with many heads, her yellow dress flicks moth wings in the dusk. ripples and flung stones, faces turn to watch her, white as a candy apple bite. hands grab at children, press them flat as bible bookmarks. the girl with many heads

passes in a wind omniscient and drenched with storm warnings. she sweeps by the ferris wheel, stars that spin within reach; its far-off screams and laughter settle on her naked neck. past the rollercoaster that snakes its track like mad blood, past the neon panda at the shooting range, helpless and waiting to be won, through the games and canned music she walks her small apocalypse. hired clowns offer her paper roses, she declines. finally she arrives at the short stairway, climbs it to the voice of led zeppelin; the ticket taker holds back the customer line. all about this place, 
dark angels ooze from the ground, white demons hiss and stroke their massive wings. there is the sound of exquisite singing as the girl with many heads enters the house of mirrors

walks into the first looking lobby, stops. all her life she has caught odd glimpses of one face or another in bathrooms, store windows, the eyes of other humans trapped by hers before they looked away. tonight she has come to face all that is hers, look direct into every aspect, every angle; the girl with many heads lifts her gaze

and she sees there are so many - gnomes with cauliflower heads, one-eyed demons that have no mouths, babies wailing for mother dreams. she sees the angels that keep cutting their wrists, the children who play with back alley dares, the dimestore novelist and the nun who memorized leviticus. witches hold out their palms pleading for a kiss, the princess blooms breasts and red lips, displays them as her anchor to the human race. there is the straight ahead face, the one that keeps the girl facing forward, turned away from her many others, muttering, no, no,

and at the center of this circus crowd she carries on her neck, the girl sees the slender drifting almost-not-there face of a woman who would stand in a watercolour painting wearing a printed dress, pigeons eating from her hand, singing yes. the girl with many heads hadn't known she carried so many necessary hearts. now she reaches in a huge echo toward many hands,

they come to her with a shattering of glass, break the boundaries between here and there, slip their breathing into the request of her lungs. she stands in her yellow dress feeding demons and angels from her many hands is gone dissolved into the watching crowd's scattering voices 